Jurnal Keolahragaan
Volume 4 - Nomor 1, April 2016,(111 - 121)
Tersedia online: http://journal.uny.ac.id/index.php/jolahraga

\title{
PENGARUH LATIHAN BEBAN DAN KEKUATAN OTOT TERHADAP HYPERTROPHY OTOT DAN KETEBALAN LEMAK
}

\author{
Eko Sucipto $^{1 *}$, Widiyanto ${ }^{2}$ \\ ${ }^{1}$ Universitas PGRI Palembang. Jalan Jend A. Yani Lrg Gotong Royong 9/10, Palembang, Indonesia. \\ ${ }^{2}$ Pendidikan Kesehatan dan Rekreasi, Universitas Negeri Yogyakarta. Jalan Colombo No 1, \\ Karangmalang Yogyakarta 55281, Indonesia \\ * Korespondensi Penulis. Email: mania_echo@ymail.com
}

\begin{abstract}
Abstrak
Penelitian ini bertujuan untuk mengetahui: (1) perbedaan pengaruh antara latihan beban dengan metode compound set dan circuit training, (2) perbedaan pengaruh antara kekuatan otot tinggi dan rendah, dan (3) interaksi antara metode latihan beban dan kekuatan otot terhadap hasil hypertrophy otot dan ketebalan lemak. Populasi dalam penelitian ini adalah 56 members yang programnya hypertrophy otot dari Fitness Centre GOR FIK UNY dan Fitness Centre Club Arena Hotel Jayakarta Yogyakarta. Sampel berjumlah 28 members yang ditentukan dengan teknik purposive rondom sampling. Teknik analisis data yang digunakan dalam penelitian ini adalah analisis varian (anava). Hasil penelitian adalah: (1) ada perbedaan pengaruh yang signifikan antara latihan beban dengan metode compound set dan circuit training terhadap hypertrophy otot, (2) ada perbedaan pengaruh kekuatan otot tinggi dan rendah terhadap hypertrophy otot dan ketebalan lemak, dan ada interaksi yang signifikan antara metode latihan beban dan kekuatan otot terhadap hypertrophy otot.
\end{abstract}

Kata Kunci: metode latihan beban, kekuatan otot, hasil hypertrophy otot dan ketebalan lemak

\section{THE EFFECT OF WEIGHT TRAINING AND MUSCLE STRENGTH ON MUSCLE HYPERTROPHY AND FAT THICKNESS}

\begin{abstract}
This study aims to find out: (1) the differences between the effect of weight training method and circuit training compound set, (2) differences in the effect of high and low muscle strength, and (3) the interaction among methods of weight training and muscle strength on the muscle hypertrophy and fat thickness. This study is experimental. The population was 56 members of Sport Hall Fitness Centre Faculty, of Sports Science, State University of Yogyakarta and Fitness Centre Club Arena Hotel Jayakarta Yogyakarta. A sample of 28 members was established using the purposive random sampling technique. The data analysis technique used in this study was the analysis of variance (ANOVA). The results show that: (1) there is a significant effect difference between the weight training and circuit training compound set on the result of muscle hypertrophy(2) there is a difference in the effect of high and low muscle strength on the results of muscle hypertrophy and fat thickness, and (3) there is a significant interaction between the weight training method and muscle strength on the muscle hypertrophy results.
\end{abstract}

Keywords: method of weight training, muscle strength, muscle hypertrophy results and fat thickness

How to Cite: Sucipto, E., \& Widiyanto, W. (2016). Pengaruh latihan beban dan kekuatan otot terhadap hypertrophy otot dan ketebalan lemak. Jurnal Keolahragaan, 4(1), 111-121. doi:http://dx.doi.org/10.21831/jk.v4i1.8131

Permalink/DOI: http://dx.doi.org/10.21831/jk.v4i1.8131 


\section{PENDAHULUAN}

Latihan beban merupakan olahraga kompetitif yang memberikan kesempatan bagi members untuk menunjukkan prestasi, baik melalui latihan di klub-klub fitness. Oleh karena itu, perlu ada upaya atau usaha mengembangkan melalui latihan dalam meningkatkan prestasi. Tercapainya presatasi tinggi diperoleh dengan latihan yang tepat dan benar, serta usaha keras yang timbul dalam diri seorang member. Selain itu member juga perlu ditunjang dari berbagai faktor, antara lain kemampuan penguasaan teknik, kondisi fisik yang prima, kualitas pelatih, dan didukung dengan motivasi yang timbul dalam diri member. Di samping itu, faktor lain yang memiliki pengaruh penting adalah disiplin ilmu yang erat hubungannya dengan olahraga dan program latihan yang direncanakan dengan baik, terarah, dan bermutu.

Latihan beban (weight training) adalah aktivitas fisik yang dilakukan secara sistematis dengan menggunakan beban sebagai alat untuk meningkatkan kekuatan otot untuk mencapai tujuan seperti memperbaiki kondisi fisik members, mencegah terjadinya cedera atau untuk tujuan kesehatan (Dreger, 2006, p.66). Suhendro (2000, p.46) menyatakan bahwa weight training berbeda dengan weight lifting. Weight lifting adalah latihan yang menekankan pada beban yang berat, yang bertujuan untuk mencapai prestasi angkat berat. Jadi seorang Member harus berlatih dengan benar sesuai dengan tujuannya. Keberhasilan seorang member dalam mencapai prestasi tinggi tidak akan tercapai tanpa latihan melalui program latihan yang sistematis, disiplin, dan motivasi diri members itu sendiri. Seperti dijelaskan oleh Sukadiyanto (2010, p.11), "Tujuan serta sasaran utama latihan atau training adalah meningkatkan kemampuan, keterampilan, dan penampilan atlet dengan bimbingan pelatih." Oleh karena itu anak latih merupakan satu totalitas sistem psikofisik yang kompleks, maka proses latihan sebaiknya tidak hanya menitikberatkan pada aspek fisik saja, melainkan juga harus melatih aspek psikis secara seimbang dengan fisik.

Dalam olahraga latihan beban diperlukan latihan yang baik dan teratur untuk mencapai hasil yang maksimum dan menuju prestasi yang lebih baik. Selain itu juga ada beberapa faktor yang harus dikuasai oleh setiap member agar mampu mencapai prestasi yang tinggi. Menurut Sukadiyanto (2010, p.5) kualitas latihan ditentukan terutama oleh keadaan dan kemampuan pelatih serta olahragawan, keduanya harus memiliki kemampuan, kemauan, dan komitmen yang tinggi untuk meraih hasil yang baik.

Di dalam program latihan beban terdapat istilah repetisi. Repetisi adalah salah satu gerakan teknik mengangkat yang dilakukan secara berulang-ulang. Pada member kurang sekali dilakukan sehingga metode yang diandalkan kurang berkembang. Latihan beban yang sering digunakan oleh member hanya metode set block.

Berdasarkan masalah tersebut, yang perlu ditingkatkan adalah bentuk latihan yang lebih bervariasi terutama pada metode latihan. Salah satu metode yang baik yaitu menggunakan compound set, dengan menggunakan dua jenis latihan yang berbeda pada saat melakukan latihan ini akan lebih membantu karena compound set lebih fokus pada sasaran sehingga menimbulkan bertambahnya atin dan myosin dan massa otot akan membesar. Selain itu, metode ini juga dapat melatih dua komponen pilar latihan yaitu dapat melatih teknik sekaligus fisik member. Metode latihan beban yang bervariasi lain adalah circuit training. Circuit training ini bisa membantu members untuk meningkatkan kekuatan, daya tahan otot, dan penurunan ketebalan lemak. Dengan menggunakan latihan variasi metode compound set dan circuit training akan dapat ditingkatkan hypertrophy otot dan penurunan ketebalan lemak member Fitness Centre GOR FIK UNY dan Fitness Centre Club Arena Hotel Jayakarta.

Menurut Irianto (2004, p.105) "metodemetode latihan ditentukan oleh isi/materi latihan, karakteristik beban, sarana dan prasarana latihan serta disesuaikan dengan keadaan paedagogis dan fisiologis atau kebutuhan-kebutuhan kelompok penerima." Sesuai dengan kemampuan kondisi yang menentukan prestasi suatu cabang olahraga, kemampuan motorik yang sesuai akan dikembangkan melalui metode-metode latihan yang tepat. Metode latihan merupakan cara-cara yang terencana secara sistematis dan beroreintasi kepada tujuan.

Members Fitness Centre GOR FIK UNY dan Fitness Centre Club Arena Hotel Jayakarta masih kurang sekali menerima bentuk-bentuk variasi latihan beban. Latihan yang diberikan pelatih hanya bersifat monoton, pelatih tidak mengarahkan members pada metode yang cocok untuk tujuan latihan beban yang diinginkan members. Program latihan yang monoton akan berdampak pada kebosanan dan kurang percaya diri untuk melakukan latihan beban. Selain itu 
program latihan yang diberikan oleh pelatih kurang sistematis, pelatih juga tidak melihat karakteristik members. Metode compound set merupakan metode yang cocok untuk menambah massa otot, karena metode compound set fokus ke sasaran otot yang dilatih dengan menggunakan dua jenis latihan yang berbeda namun mengenai satu sasaran otot. Berbeda dengan metode compound set, metode circuit training lebih cocok untuk menambah daya tahan otot, kekuatan, dan lebih cocok untuk penurunan ketebalan lemak karena metode circuit training ini sifatnya melatih seluruh bagian otot dan tidak fokus ke sasaran satu otot. Oleh sebab itu, members yang mau menambah massa otot harus menggunakan metode compound set, sebaliknya yang ingin mengurangi kadar lemak dalam tubuh lebih cocok menggunakan metode circuit training.

Ditinjau dari sifat dasar, ada lima karakteristik mahasiswa dalam proses pembelajaran yaitu: (1) intelegensi, (2) sikap, (3) bakat, (4) minat, dan (5) motivasi (Syah, 2003, p.142). Meskipun demikian, untuk mencapai sukses, mahasiswa dituntut untuk bertekad dan berusaha agar menjadi mahasiswa yang unggul, penuh semangat, dan penuh gairah mengikuti studi. Penelitian ini dilakukan di Fitness Centre GOR FIK UNY dan Fitness Centre Club Arena Hotel Jayakarta. Penelitian dilakukan di sana karena kedua tempat tersebut memiliki karakteristik yang identik.

Karakteristik member yang latihan beban berbeda dengan member yang latihan lainnya. Perbedaan ini berdasarkan bidangnya, latihan beban bergerak dalam bidang olahraga yang berarti akan membentuk ciri-ciri yaitu: (1) dari segi fisik member yang mengikuti kegiatan latihan dengan rutin akan memiliki kualitas fisik yang baik, karena terbiasa dengan latihan dilakukan selama tiga kali seminggu, sehingga members yang melakukan kegiatan latihan beban tidak akan mudah sakit, hal ini sesuai dengan slogan dalam bahasa Romawi Kuno "Orandum Est ut sit Mens Sana In Corporesano" yang berarti di dalam tubuh yang sehat diharapkan juga terdapat jiwa yang sehat, (2) dari segi psikis apabila ditinjau dari segi mental dan sifat members yang melakukan latihan beban akan membentuk mental dan sifat yang baik, karena latihan beban yang bergerak dalam bidang olahraga menjunjung tinggi sportivitas baik di dalam atau di luar lapangan. Karakteristik member menurut pendapat Syah (2003, p.145) terdiri atas: (1) sikap, (2) minat, dan (3) motivasi.

Irianto $(2000$, p.59) menyatakan bahwa latihan beban merupakan suatu bentuk latihan yang menggunakan media alat beban untuk menunjang proses latihan dengan tujuan untuk meningkatkan kebugaran, kekuatan otot, kecepatan, pengencangan otot, hypertrophy otot, rehabilitasi pascacedera, penurunan berat badan, dan lain-lain. Dreger dalam Suharjana (2007, p.18) menyatakan bahwa latihan beban adalah latihan yang sistematis yang menggunakan beban sebagai alat untuk menambah kekuatan otot guna mencapai kondisi fisik atlet, mencegah terjadinya cedera atau untuk tujuan kesehatan. Latihan beban tubuh akan dipaksa menyesuaikan diri dengan membesarnya jaringan otot yang dilatih. Dalam latihan aerobik, tubuh akan beradaptasi dengan cara meningkatnya efisiensi fisiologis yang menyebabkan peningkatan stamina. Terdapat beberapa macam sistem latihan yang digunakan dalam latihan beban, khususnya untuk hypertrophy otot di antaranya sebagai berikut: (1) super set, (2) set system, (3) compound set, (4) pyramide, (5) drop set, (6) triset, (7) giant set, (8) circuit training, (9) staggered set, (10) rest pause, (11) preexhaustion, (12) descending set, dan (13) compound set dengan circuit training.

Irianto (2004, p.42-43) menyatakan bahwa metode latihan compound set adalah melatih satu kelompok otot secara berurutan dengan bentuk latihan yang berbeda. Metode latihan menggunakan sistem ini sangatlah baik untuk program hypertrophy atau pembentukan otot bagi body builder.

Latihan sirkuit yang paling tepat untuk pembakaran lemak adalah circuit weight training. Program latihan di atas dapat digunakan sebagai program pembakaran lemak (penurunan berat badan). Program ini dapat berjalan optimal dengan hasil yang memuaskan apabila dilakukan sesuai dengan takaran latihan yang ada. Weight training dapat digunakan sebagai model latihan untuk menurunkan berat badan asal memenuhi persyaratan, antara lain menggunakan sistem sirkuit, detak jantung dapat dipertahankan $65 \%-75 \%$ detak jantung maksimal, dan dikerjakan lebih dari 20 menit (Irianto, 2004, p.84).

Program ini juga dapat diikuti dengan pengaturan pola makan yang baik serta istirahat yang sesuai. Penurunan berat badan yang efektif yaitu turun secara bertahap dan yang aman yaitu $0,5 \mathrm{~kg}$ sampai $1 \mathrm{~kg}$ per minggu. Latihan 
dilakukan 4 kali dalam 1 minggu dengan variasi latihan yang berbeda pada tiap 1 kali sesi latihan. Variasi dalam latihan beban dapat mengurangi rasa jenuh dan yang terpenting adalah semakin banyak otot yang dilatih sehingga pembakaran lemak dalam otot diharapkan lebih kompleks perkenaannnya.

Mukholid (Hasibun, 2010, p.43) mengartikan kekuatan sebagai, "Kemampuan otot untuk membangkitkan tegangan terhadap suatu tahanan. Oleh karena itu latihan yang cocok untuk mengembangkan kekuatan tubuh adalah latihan tahanan (resistance exercises). Contoh latihan tahanan adalah mengangkat, mendorong atau menarik suatu beban. Beban yang dimaksud bisa berupa beban anggota tubuh sendiri, ataupun beban dari luar." Agar efektif hasilnya, latihan-latihan tahanan dilakukan dengan mengupayakan agar tenaga yang dikeluarkan untuk menahan beban semaksimal mungkin. Suharjana (2007, p.46) menyatakan latihan kekuatan menghasilkan hypertrophy otot dan daya tahan otot untuk meningkatkan jumlah kapiler.

Salah satu tujuan latihan kekuatan adalah meningkatkan ukuran besarnya serabut otot atau yang disebut hypertrophy otot. Hypertrophy akan terjadi setelah latihan selama delapan minggu atau lebih, sehingga ukuran pada otot akan kelihatan. Program latihan dengan menggunakan beban dari luar tubuh (weight training) akan mempercepat proses terjadinya hypertrophy otot (Sukadiyanto, 2005, p.91). Terjadinya hypertrophy otot menurut Bompa dalam Sukadiyanto (2005, p.91) sebagai akibat dari bertambahnya myofibril pada setiap serabut otot, meningkatnya densitas (kepadatan) kapiler pada setiap serabut otot, meningkatnya jumlah protein, dan bertambah jumlah serabut otot. $\mathrm{Mc}$ Ardle, et.al dalam Sukadiyanto (2005, p.91) menyatakan hypertrophy akan terjadi pada orang yang melakukan latihan dengan beban yang ditandai dengan bertambah besarnya otot putih (cepat) kira-kira $45 \%$ apabila dibandingkan dengan orang awam atau olahragawan yang memerlukan ketahanan.

Rai, Hamid \& Tsiang (2007, p.29) menyatakan bahwa hypertrophy otot adalah pertumbuhan massa otot yang menyebabkan serabut otot bertambah besar atau tebal. Perekrutan serabut otot yang maksimal (maximum muscle fibre recruitmen) terjadi saat seluruh serabut otot yang dilatih benar-benar terpakai semua untuk menggerakan tekanan beban yang ditempatkan pada bagian otot tersebut. Perekrutan serabut otot yang maksimal harus terjadi untuk bisa mendapatkan pertumbuhan otot yang maksimal, karena tanpa perekrutan seluruh serabut otot pada bagian tubuh yang dilatih, potensi perkembangan otot hanya sekecil jumlah serabut otot yang dipakai. Artinya, semakin banyak atau maksimal serabut otot direkrut dalam satu sesi latihan, semakin besar potensi perkembangan massa otot (hypertrophy).

Jadi dapat disimpulkan, hypertrophy adalah akibat dari peningkatan jumlah filamen aktin dan miosin dalam setiap serabut otot. Selama terjadi hypertrophy, sintesis protein kontraktil otot berlangsung lebih cepat dari penghancurannya, sehingga menghasilkan jumlah filamen aktin dan miosin bertambah banyak dalam myofibril. Myofibril sendiri akan memecah dalam serabut otot untuk membentuk myofibril yang baru, hal ini yang disebut hypertrophy otot.

Schoenfeld (2010, p.2857) menyatakan bahwa meskipun hypertrophy otot dapat dicapai melalui berbagai program pelatihan resistensi, prinsip kekhususan menyatakan beberapa rutinitas akan memromosikan hypertrophy lebih besar daripada yang lain. Binaragawan umumnya berlatih dengan beban moderat dan interval istirahat yang cukup pendek yang menginduksi jumlah stress metabolik yang tinggi. Hypertrophy otot dapat dianggap berbeda dan terpisah dari hiperflasia otot. Selama hypertrophy, elemen kontraktil memperbesar dan matriks ekstraseluler memperluas untuk mendukung pertumbuhan. Hal ini berbeda dengan hiperflasia, yang menghasilkan pe-ningkatan jumlah serat dalam otot. Kontraktil hypertrophy dapat terjadi baik dengan me-nambahkan sarkomer secara seri atau paralel. Sel-sel satelit diperkirakan memfasilitasi hypertrophy otot dalam beberapa cara.

Definisi lain dari lemak menurut Irianto (2007, p.9) adalah garam yang terbentuk dari penyatuan asam lemak dengan alkohol organik yang disebut gliserol atau gliserin. Lebih lanjut dijelaskan bahwa lemak dikelompokkan menjadi beberapa jenis meliputi: (1) simple fat (lemak sederhana atau lemak bebas), (2) lemak ganda, dan (3) derivat lemak.

Ilhamjaya (2000, p.41) menyatakan bahwa sebagaimana karbohidrat, lemak juga mempunyai bentuk dasar yang digunakan dalam tubuh, yaitu asam lemak. Lemak diperoleh dari diet yang dicerna, memroduksi asam lemak dan sebuah substansi yang disebut gliserol. Setelah asam lemak diabsorbsi melalui sel saluran cerna, selanjutnya akan diubah menjadi trigliseri- 
da. Trigliserida terdiri atas $1 \mathrm{~mol}$ gliserol dan 3 mol asam lemak. Trigliserida dapat dipecah menjadi gliserol dan asam lemak. Asam lemak disimpan sebagai trigliserida. Simpanan trigliserida ditemukan dalam jaringan lemak dan di dalam sel otot rangka. Ketika dibutuhkan oleh otot, asam lemak dari jaringan lemak dilepaskan dari trigliserida dan menuju otot melalui darah. Mobilisasi asam lemak dari cadangan lemak tubuh ke otot merupakan suatu hal penting untuk mengurangi berat badan melalui pembuangan lemak tubuh.

Ada dua bentuk utama dari bahan bakar yang disediakan untuk otot selama latihan: (1) asam lemak yang ditransportasi melalui darah dari jaringan lemak, dan (2) simpanan trigliserida yang terdapat di dalam sel otot sendiri. Dalam melakukan aktivitas fisik dibutuhkan energi yang berasal dari pembakaran karbohidrat, lemak, dan protein yang disesuaikan dengan tipe kerja otot dan intensitas latihan. Pembakaran karbohidrat sebagai sumber energi digunakan pada aktivitas yang berat dengan jangka waktu latihan yang pendek, sedangkan pembakaran lemak sebagai sumber energi digunakan untuk aktivitas atau latihan yang berat denga jangka waktu yang lama.

Fox dalam Suharjana $(2008$, p.44) menyatakan bahwa untuk mengetahui ketebalan lemak tubuh dapat diukur pada lipatan kulit di daerah bagian tertentu. Salah satu alat yang digunakan untuk mengukur ketebalan lemak kulit adalah dengan skinfold calipters. Johnson dalam Suharjana (2008, p.44) menyatakan bahwa untuk pengukuran tebal lemak, ada tiga tempat yang dapat diukur, untuk pria, yaitu pada chest, abdomen, dan thigh. Cara mengestimasi ketebalan lemak dengan menggunakan monogram yaitu dengan membuat garis lurus yang menggabungkan antara usia (age) dan tebal lipatan lemak dalam mm.

Sharkey (2011, pp.280-283) menyatakan bahwa metode standar untuk menentukan kelebihan berat badan adalah dengan membandingkan berat badan seseorang dengan berat badan ideal. Berat badan ideal adalah berat badan yang berkaitan dengan jangka hidup yang panjang bagi individu yang memiliki ukuran rangka tulang tertentu. Kelebihan berat badan berkaitan dengan penyakit jantung, diabetes, dan hypertensi. Kelebihan pon-pon lemak atau otot dapat membuat kelebihan berat badan, tetapi lemak tambahan menghasikan banyak beban karena otot dapat melakukan kerja yang bermanfaat dan membutuhkan ruang yang lebih sedikit untuk berat yang sama. Walau demikian kelebihan berat otot tidak begitu penting bagi orang dewasa, kecuali untuk alasan pekerjaan.

Kegemukan adalah kasus kelebihan lemak, bukan sekedar kasus kelebihan berat badan. Mungkin saja berat badan ringan dan masih tetap gemuk, seperti apabila individu memiliki lemak yang berlebihan dan otot yang tidak berkembang. Kegemukan dapat diartikan sebagai lebih dari $20 \%$ di atas berat badan ideal, atau lebih dari $20 \%$ lemak untuk pria dan $30 \%$ lemak untuk wanita.

Menurut Bompa \& Haff (2009, p.129), "Training is usually defined as systematic process of repetitive, progressive exercises, having the ultimate goal of improving athletic perfor-mance." Maksudnya latihan sebagai suatu proses sistematis yang dilakukan secara berulang-ulang, progresif, dan mempunyai tujuan untuk meningkatkan penampilan fisik.

Irianto $(2004$, p.12) menyatakan bahwa untuk mencapai tujuan latihan atau fitness secara optimal, orang perlu mengetahui prinsipprinsip dasar dalam latihan fitness yang memiliki peranan yang sangat penting terhadap aspek fisiologis maupun psikologis. Husein et.al. (2007, pp.46-52) menyatakan bahwa prinsip latihan ada empat yaitu prinsip pedagogik, prinsip individual, prinsip keterlibatan aktif, dan prinsip variasi.

Power \& Howlen (2007, p.621) menyatakan, "Overload refers to the observation that a system or tissue must be exercised at a level beyond which it is accustomed in order for a training effect to occur." Artinya, prinsip beban berlebih dimaksudkan untuk penelitian sistem atau isu yang harus dilakukan pada level di luar kemampuan yang disesuaikan dengan efek latihan. Di sisi lain, Irianto (2004, p.12) menyatakan yang dimaksud dengan prinsip beban berlebih adalah pembebanan dalam latihan harus lebih berat dibandingkan dengan aktivitas fisik sehari-hari. Pembebanan harus terus ditingkatkan secara bertahap sehingga mampu memberikan pembebanan pada fungsi tubuh.

Bompa \& Haff (2009, p.54) menyatakan bahwa semua komponen latihan harus ditingkatkan sesuai dengan perbaikan atau kemajuan yang dicapai atlet secara keseluruhan dan terpantau dengan benar. Dalam merancang suatu proses latihan harus mempertimbangakan semua aspek komponen latihan yang berupa jarak yang ditempuh dan jumlah pengulangan (volume), beban dan kecepatannya (intensitas), frekuensi penampilan (densitas), serta komplek- 
sitas latihannya. Komponen latihan merupakan kunci atau hal penting yang harus dipertimbangkan dalam menentukan dosis dan beban latihan.

Beberapa macam komponen latihan menurut Bompa \& Haff (2009, p.78) antara lain volume latihan, intensitas latihan, densitas latihan, dan kompleksitas latihan.

\section{METODE}

\section{Jenis Penelitian}

Penelitian ini adalah penelitian eksperimen yang bertujuan untuk membandingkan dua perlakuan yang berbeda pada subjek penelitian. Adapun jenis penelitian yang digunakan dalam penelitian ini adalah eksperimen dengan desain faktorial $2 \times 2$, dengan menggunakan tes awal (pretest) dan tes akhir (posttest). Menurut Sudjana (2002, p.148) eksperimen faktorial adalah eksperimen yang hampir semua faktor dikombinasikan atau disilangkan dengan tiap faktor lainnya yang ada dalam eksperimen. Rancangan penelitian selengkapnya dapat dilihat pada Tabel 1.

Tabel 1. Desain Penelitian Faktorial 2x2

\begin{tabular}{ccc}
\hline $\begin{array}{c}\text { Variabel } \\
\text { Manipulatif }\end{array}$ & \multicolumn{2}{c}{ Metode Latihan Beban } \\
\cline { 1 - 3 } Kekuatan Otot & $\begin{array}{c}\text { Compound Set } \\
\left(\mathrm{A}_{1}\right)\end{array}$ & $\begin{array}{c}\text { Circuit Training } \\
\left(\mathrm{A}_{2}\right)\end{array}$ \\
\hline Tinggi $\left(\mathrm{B}_{1}\right)$ & $\mathrm{A}_{1} \mathrm{~B}_{1}$ & $\mathrm{~A}_{2} \mathrm{~B}_{1}$ \\
Rendah $\left(\mathrm{B}_{2}\right)$ & $\mathrm{A}_{1} \mathrm{~B}_{2}$ & $\mathrm{~A}_{2} \mathrm{~B}_{2}$ \\
\hline
\end{tabular}

Keterangan:

$\mathrm{A}_{1} \mathrm{~B}_{1}$ : Kelompok kekuatan otot tinggi yang dilatih dengan menggunakan metode Coumpound Set.

$\mathrm{A}_{2} \mathrm{~B}_{1}$ : Kelompok kekuatan otot tinggi yang dilatih dengan menggunakan metode Circiut Training.

$\mathrm{A}_{1} \mathrm{~B}_{2}$ : Kelompok kekuatan otot rendah yang dilatih dengan menggunakan metode Coumpound Set.

$\mathrm{A}_{2} \mathrm{~B}_{2}$ : Kelompok kekuatan otot rendah yang dilatih dengan menggunakan metode Circiut Training.

Hasil eksperimen yang menggunakan desain faktorial akan memperoleh informasi tetang kontribusi tiap-tiap variabel independen terhadap hasil perlakuan dan interaksi di antara variabel yang dilibatkan. Kelebihan menggunakan penelitian eksperimen desain faktorial adalah kemampuan untuk memperoleh informasi mengenai interaksi di antara variabel independen yang memengaruhi variabel dependen.

\section{Waktu dan Tempat Penelitian}

Penelitian ini dilaksanakan di Fitness Centre Club Arena yang ada di Jalan Solo Km 8 Hotel Jayakarta dan Fitness Centre GOR FIK UNY yang beralamat di Jalan Colombo 1, Yogyakarta. Penelitian ini dilakukan pada tanggal, 4 November s.d. 23 Desember 2013 selama sepuluh minggu. Pemberian treatment dilakukan selama 8 minggu dengan frekuensi pertemuan 3 kali per minggu. Hal ini sesuai dengan pendapat Bompa \& Haff (2009, p.207), maksudnya adalah agar tubuh beradaptasi dengan beban latihan yang diterima.

\section{Populasi dan Sampel Penelitian}

Sudjana (2002, p.6) menyatakan bahwa populasi adalah totalitas semua nilai yang mungkin, hasil menghitung ataupun pengukuran kuantitatif kualitatif, mengenai karakteristik tertentu dari semua anggota kumpulan lengkap dan jelas, yang dipelajari sifat-sifatnya. Dalam suatu proses penelitian, tidak perlu seluruh populasi diteliti, akan tetapi dapat dilakukan terhadap sebagian dari jumlah populasi tersebut. Sebagaimana yang dikemukakan oleh Arikunto (2006, p.131) bahwa sampel adalah sebagian atau wakil dari populasi yang diteliti.

Adapun teknik pengambilan sampel dalam penelitian ini adalah dengan cara purposive random sampling. Berdasarkan teori di atas, sampel yang diambil adalah members Fitness Centre GOR FIK UNY dan Fitness Centre Club Arena Hotel Jayakrta. Besar sampel yang akan digunakan dalam penelitian ini adalah 27 $\%$ batas atas dan $27 \%$ batas bawah setelah dilakukan tes leg and back dynamometer pada populasi (Miller, 2002, p.68). Dengan demikian sampel yang digunakan dalam penelitian harus memenuhi ketentuan: (1) merupakan members Fitness Centre GOR FIK UNY dan Fitness Centre Club Arena Hotel Jayakarta, (b) bersedia mengikuti latihan beban sebanyak 20 kali pertemuan, 1 kali pretest, dan 1 kali posttest, (c) sehat jasmani dan rohani, (d) belum pernah dan sudah terlatih, dan (e) sampel dinyatakan gugur jika 2 kali berturut-turut tidak mengikuti latihan. Alasannya, jika anak latih tidak mengikuti latihan selama $2 \times 24$ jam, kondisi tubuh dalam menerima rangsang kembali ke tahap semula atau latihan mulai dari awal.

Dari 28 members yang memiliki kekuatan otot tinggi tadi diambil 7 members diberi perlakuan dengan metode compound set dan 7 members diberi perlakuan metode circuit train- 
ing. Demikian pula dengan members yang memiliki kekuatan otot rendah diperlakukan dengan cara yang sama. Dari 28 members setelah dilakukan pretest dipisahkan menjadi 2 kelompok yang seimbang. Pengelompokan yang seimbang menggunakan ordinal pairing. Sampel yang memiliki kemampuan setara dipasangkan, kemudian anggota tiap pasangan dipisah dalam dua kelompok eksperimen didasarkan pada kemampuan kekuatan otot pada saat pretest. Setelah hasil awal diranking kemudian subjek yang memiliki kemampuan dipasangkan ke dalam kelompok 1 (K 1, latihan beban dengan metode compound set) dan dalam kelompok 2 (K 2, latihan beban dengan metode circuit training). Dengan demikian kedua kelompok tersebut diberi perlakuan yang berbeda dan pada akhirnya terdapat perbedaan perlakuan yang diberikan. Berdasarkan hal tersebut didapat 14 members yang memiliki kekuatan tinggi dan 14 members yang memiliki kekuatan rendah. Kelompok members yang memiliki kekuatan otot tinggi dan kekuatan otot rendah masing-masing dibagi menjadi dua kelompok dengan cara ordinal pairing, yaitu 7 members mendapat metode compound set dan 7 members mendapat metode circuit training. Jadi, besar sampel dalam penelitian ini adalah 28 members yang terdiri atas 14 members yang memiliki kekuatan otot tinggi dan 14 members yang memiliki kekuatan otot rendah. Adapun teknik pembagian kelompok dengan ordinal pairing menurut Sutrisno Hadi dalam Dinata, Sutardji, \& Waluyo (2013, p.26) seperti pada Gambar 6.

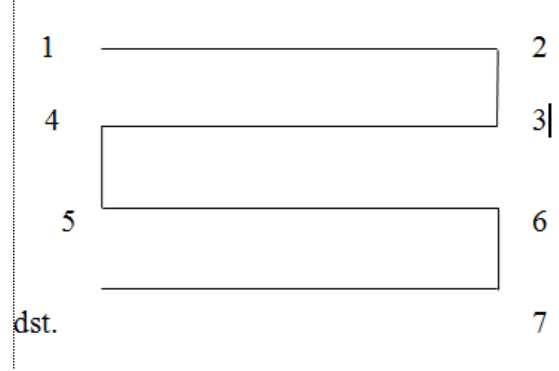

Gambar 6. Pembagian Kelompok dengan Ordinal Pairing

\section{Variabel Penelitian}

Penelitian ini melibatkan 2 variabel bebas yang dimanipulasi, 1 variabel bebas yang dikendalikan (atribut), 1 variabel terikat dan 1 variabel moderator. Variabel bebas yang dimanipulasi terdiri atas: (1) metode compound set dan (2) metode circuit training. Metode compound set merupakan metode melatih satu kelompok otot secara berurutan dengan bentuk latihan yang berbeda. Metode circuit training merupakan suatu metode latihan fisik yang melibatkan latihan kebugaran jasmani dan latihan kekuatan dan fatloss.

Variabel bebas yang dikendalikan (atribut) adalah kekuatan otot, yang terdiri atas (1) kekuatan otot tinggi dan (2) kekuatan otot rendah. Kekuatan otot merupakan komponen kondisi fisik yang dapat ditingkatkan sampai batas submaksimal. Kekuatan otot adalah kemampuan untuk membangkitkan tegangan terhadap suatu tahanan.Variabel terikat adalah hypertrophy otot dan ketebalan lemak.

\section{Data, Instrumen, dan Teknik Pengumpulan Data}

Prinsip suatu penelitian adalah melakukan pengukuran dan harus ada alat ukur yang baik. Oleh Sugiyono (2007, p.102) dikatakan alat ukur atau instrumen penelitian adalah suatu alat yang digunakan untuk mengukur fenomena alam maupun sosial yang diamati, secara spesifik, semua fenomena itu disebut variabel penelitian. Instrumen penelitian secara garis besar bisa digolongkan menjadi dua, yaitu berbentuk tes dan nontes. Penelitian ini mengunakan instrumen tes. Mengenai tes adalah serentetan pertanyaan atau latihan serta alat lain yang digunakan untuk mengukur kekuatan otot, yang dimiliki oleh individu atau kelompok. Adapun instrumen penelitian yang digunakan dalam penelitian ini adalah tes kekuatan otot dengan menggunakan leg and back dynamometer.

\section{Teknik Analis Data}

Setelah diperoleh data hypertrophy otot dan ketebalan lemak, langkah selanjutnya adalah mengolah dan menganalisis data tersebut. Pada bagian ini akan diuraikan mengenai teknik analisis data hasil tes, terhadap metode compound set dan circuit training. Teknik analisis data yang digunakan adalah teknik analisis varian (anava) dua jalur pada $\alpha=5 \%$. Jika $F$ yang diperoleh $\left(\mathrm{F}_{0}\right)$ signifikan analisis dilanjutkan dengan uji perbedaan seluruh kelompok dan antardua kelompok yaitu dengan uji-t dan anava dua jalur. Untuk memenuhi asumsi dalam teknik anava, terlebih dahulu dilakukan uji normalitas dengan uji kolmogorov smirnov dan uji homogenitas varians dengan menggunakan uji bartlett. Untuk menguji hipotesis dilakukan dengan menggunakan anava dua jalur dan apabila terbukti terdapat interaksi akan dilakukan uji lanjutan yaitu uji pairwise comparisons. 


\section{HASIL DAN PEMBAHASAN}

Hasil penelitian menunjukkan bahwa ada perbedaan pengaruh antara metode compound set dan circuit training terhadap hypertrophy otot dan ketebalan lemak pada members Fitness Centre GOR FIK UNY dan Fitness Centre Club Arena Hotel Jayakarta. Berdasarkan nilai signifikansi univariat test sebesar sebesar 0,00 $<0,05$ dan 0,001 < 0,05 yang berati bahwa lebih kecil dari signifikan. Dengan demikian hipotesis 1 yang menyatakan ada perbedaan pengaruh antara metode compound set dan circuit training terhadap hypertrophy otot dan ketebalan lemak yang baik, diterima. Dari analis lanjutan diperoleh bahwa ternyata metode compound set memiliki peningkatan yang lebih baik daripada metode circuit training. Dengan demikian metode compound set lebih bagus daripada metode circuit training pada masa sebelum retensi, sebagai hasil fase latihan.

Hasil penelitian menunjukkan bahwa ada perbedaan peningkatan hasil hypertrophy otot dan ketebalan lemak antara members yang memiliki kekuatan otot tinggi dan rendah. Berdasarkan nilai signifikansi univariate test sebesar $0,007<0,05$ dan $0,002<0,05$ yang berarti bahwa lebih kecil dari signifikan. Dengan demikian hipotesis 2 yang menyatakan ada perbedaan peningkatan hasil hypertrophy otot dan ketebalan lemak yang baik antara members yang memiliki kekuatan otot tinggi dan rendah, diterima. Dari analisis lanjutan diperoleh bahwa members yang memiliki kekuatan otot rendah memiliki peningkatan hypertrophy otot dan penurunan lemak yang lebih baik daripada members yang memiliki kekuatan otot tinggi, dengan rata-rata peningkatan dan penurunan masing-masing yaitu members yang memiliki kekuatan otot rendah memiliki peningkatan hypertrophy otot 172,686 serta penurunan ketebalan lemak 34,929 dan members yang memiliki kekuatan otot tinggi 165,529 serta penurunan ketebalan lemak 29,857. Dengan demikian members yang memiliki kekuatan otot rendah lebih bagus daripada members yang memiliki kekuatan otot tinggi pada masa sebelum retensi, sebagai hasil fase latihan.

Hasil penelitian menunjukkan bahwa ada interaksi antara metode latihan beban dan kekuatan otot terhadap hypertrophy otot dan ketebalan lemak yang baik pada members Fitness Centre GOR FIK UNY dan Fitness Centre
Club Arena Hotel Jayakarta. Berdasarkan hasil perhitungan tests of between-subjects effects didapat bahwa taraf signifikansi hypertrophy otot sebesar $0,00<0,05$ dan ketebalan lemak sebesar $0,00<0,05$, hal ini menunjukkan bahwa tingkat signifikasi $5 \%$ ada pengaruh bersama antara metode latihan beban dan kekuatan otot terhadap hypertrophy otot dan ketebalan lemak members. Dengan demikian hipotesis 3 yang menyatakan bahwa ada interaksi antara metode latihan beban dan kekuatan otot terhadap hypertrophy otot dan ketebalan lemak yang baik pada members Fitness Centre GOR FIK UNY dan Fitness Centre Club Arena Hotel Jayakarta, diterima.

\section{Pembahasan}

Perbedaan Pengaruh antara Latihan dengan Metode Compound Set dan Circuit Training terhadap Hypertophy Otot dan Ketebalan Lemak

Berdasarkan pengujian hipotesis pertama ternyata ada perbedaan pengaruh yang nyata antara kelompok members yang mendapatkan latihan beban dengan metode compound set dan circuit training terhadap hypertrophy otot dan ketebalan lemak yang diterapkan di Fitness Centre GOR FIK UNY dan Fitness Centre Club Arena. Pada kelompok members yang dilatih dengan compound set mempunyai peningkatan hasil hypertrophy otot lebih baik daripada kelompok members yang dilatih dengan circuit training terhadap hasil hypertrophy otot. Pada kelompok members yang dilatih dengan circuit training mempunyai penurunan hasil ketabalan lemak lebih baik daripada kelompok members yang dilatih dengan compound set terhadap hasil ketebalan lemak.

Irianto (2004, pp.42-43) menyatakan bahwa metode latihan compound set adalah melatih satu kelompok otot secara berurutan dengan bentuk latihan yang berbeda. Metode latihan menggunakan sistem ini sangatlah baik untuk program pembesaran (hypertrophy) atau pembentukan otot bagi body builder.

Metode compound set apabila ditinjau dari metode latihannya metode compound set dapat melatih otot yang sama dan dua jenis alat yang berbeda hal ini sangat berguna bagi setiap members yang tujuan latihannya hypertrophy otot. Metode compound set dapat dilakukan setiap kali dalam latihan. Selain itu metode compound set bisa menerapkan program variasi latihan baik repetisi maupun set dalam mela- 
kukan latihan beban. Oleh karena itu, metode compound set dapat meningkatkan hypertrophy otot juga dapat meningkatkan fisik members apabila bentuk latihannya bervariasi.

Latihan dengan metode circuit training merupakan salah satu bentuk variasi latihan dengan menggunakan beban antarpos. Pada saat melakukan metode ini akan lebih membantu karena circuit training dapat meningkatkan kebugaran dan fisik, dan menurunkan kadar lemak dalam tubuh karena melakukan latihan beban antarpos.

Jika dilihat dari kelebihan masing-masing, tampak bahwa metode compound set memiliki sedikit kelebihan jika dibandingkan dengan circuit training. Hal ini disebabkan oleh metode compound set bisa diterapkan pada semua members dengan program hypertophy yang memiliki kekuatan otot tinggi atau rendah. Di sisi lain, metode circuit training bisa diterapkan pada semua members yang mempunyai program kebugaran jasmani dan penurunan lemak yang memiliki kekuatan otot tinggi dan rendah.

Berdasarkan kajian tersebut, tampak bahwa metode latihan compound set lebih baik daripada metode circuit training. Dapat disimpulkan bahwa metode compound set lebih baik jika dibandingkan dengan metode circuit training terhadap hasil hypertrophy otot. Berdasarkan kajian teori dan hasil penelitian dapat disimpulkan bahwa metode circuit training lebih cocok bagi members dengan program latihan penurunan lemak dan metode compound set lebih baik apabila diterapkan untuk members dengan tujuan hypertrophy otot.

Perbedaan Pengaruh antara Kekuatan Otot Tinggi dan Rendah terhadap Hypertrophy Otot dan Ketebalan Lemak

Irianto $(2009$, p.31) mengatakan peningkatan kekuatan otot bergantung pada beberapa faktor yang dapat disesuaikan dengan latihan. Misal, pada latihan kekuatan (weight training), jenis serabut otot akan memengaruhi kerja lebih efisien dan lebih responsif terhadap rangsang yang datang pada susunan saraf pusat. Keuntungan para members yang memiliki kualitas kekuatan yang baik, antara lain: (1) akan memudahkan members dalam menampilkan berbagai kemampuan gerak dan keterampilan, (2) menghindarkan diri dari kemungkinan akan terjadinya atau mendapatkan cedera pada saat melakukan aktivitas fisik, (3) memungkinkan members untuk dapat melakukan gerak yang ekstrem, dan (4) memperlancar aliran darah sehingga sampai pada serabut otot. Oleh karena itu kekuatan merupakan unsur dasar yang juga harus ditingkatkan, terutama pada members yang masih muda usianya.

Kekuatan yang dimiliki oleh members tidaklah sama, ada yang tinggi dan ada yang rendah, dan ini tentunya akan memengaruhi terhadap hypertrophy otot. Bagi members yang memiliki kekuatan tinggi tentunya akan mudah melakukan latihan beban yang berat secara maksimal, sedangkan bagi members yang memiliki kekuatan rendah akan mengalami kesulitan dalam melakukan latihan. Dari hasil penelitian diketahui bahwa kekuatan otot tinggi lebih baik hasilnya jika dibandingkan dengan kekuatan otot rendah. Meskipun demikian, jika ditelusuri pada setiap kelompok bahwa kekuatan otot rendah mengalami hasil lebih baik ketika diberikan treatment latihan beban dengan metode compound set. Hal ini disebabkan oleh latihan beban dengan metode compound set lebih membantu dan memudahkan members untuk pembesaran massa otot, karena kekuatan otot rendah harus menyesuikan gerakan yang benar sehingga akan memudahkan untuk terjadi hypertrophy otot.

Pengaruh Interaksi antara Latihan Compound Set dan Circuit Training serta Kekuatan Otot Tinggi dan Rendah terhadap Hypertrophy

Berdasarkan hasil yang telah dikemukakan pada hasil penelitian di atas bahwa terdapat interaksi yang berarti antara metode compound set, circuit training, dan kekuatan otot terhadap hypertrophy otot dan ketebalan lemak members Fitness Centre GOR FIK UNY dan Fitness Centre Club Arena Hotel Jayakarta. Dari tabel yang disajikan bentuk interaksi tampak bahwa faktor-faktor utama penelitian dalam desain dua faktor menunjuk-kan interaksi yang nyata.

Dengan demikian, untuk mengoptimalkan hypertrophy dan ketebalan lemak members apabila members tersebut memiliki kekuatan otot rendah, members tersebut lebih cocok dilatih dengan metode compound set dan members yang memiliki kekuatan otot tinggi lebih cocok dilatih dengan circuit training. Mengapa compound set lebih cocok untuk members yang memiliki kekuatan rendah? Hal ini dikarenakan members dengan kekuatan otot rendah belum terlatih sehingga untuk terjadi hypertrophy akan lebih cepat perkembanganya, karena compound set bersifat fokus melatih pada satu otot sehingga members akan terbantu untuk melaku- 
kan latihan beban. Sebaliknya, members dengan kekuatan otot tinggi lebih cocok dengan metode circuit training. Hal ini dikarenakan sifat dari circuit training bersifat seperti latihan daya tahan otot dan kecepatan sehingga cocok untuk members yang mempunyai program penurunan ketebalan lemak. Berdasarkan kajian teori dan hasil penelitian dapat disimpulakan bahwa metode circuit training lebih cocok bagi members yang ingin menurunkan ketebalan lemak dan compound set akan lebih baik untuk members yang mem-punyai program hypertrophy otot.

\section{SIMPULAN DAN SARAN}

\section{Simpulan}

Ada perbedaan pengaruh yang signifikan antara metode compound set dan circuit training terhadap hypertrophy otot dan ketebalan lemak. Pengaruh metode compound set lebih baik daripada circuit training dalam meningkatkan hypertrophy otot. Di sisi lain, pengaruh metode circuit training lebih baik daripada compound set dalam menurunkan ketebalan lemak.

Ada perbedaan yang signifikan antara members yang memiliki kekuatan otot tinggi dan rendah terhadap peningkatan hypertrophy otot dan ketebalan lemak. Peningkatan hasil hypertrophy otot dan ketebalan lemak pada members yang memiliki kekuatan otot rendah lebih baik daripada yang memiliki kekuatan otot tinggi.

Ada interaksi antara metode latihan beban (compound set dan circuit training) dan kekuatan terhadap hypertrophy otot dan ketebalan lemak pada members Fitness Center GOR FIK Universitas Negeri Yogyakarta dan Fitness Center Club Arena Hotel Jayakarta. Members yang memiliki kekuatan otot rendah lebih cocok jika diberikan metode compound set terhadap hypertrophy otot. Members yang memiliki kekuatan otot rendah lebih cocok jika diberikan metode circuit training terhadap penurunan ketebalan lemak.

\section{Saran}

Latihan compound set memiliki pengaruh yang lebih baik dalam meningkatkan hasil hypertrophy otot, sehingga pelatih atau pembina olahraga sebaiknya memilih latihan compound set dalam upaya meningkatkan hypertrophy otot.

Latihan beban dengan metode compound set dan cicuit training perlu memperhatikan faktor kekuatan otot dalam program latihan untuk meningkatkan hypertrophy otot dan menurunkan ketebalan lemak. Dalam upaya meningkatkan hypertrophy otot, atlet yang memiliki kekuatan otot rendah akan lebih tepat dan efektif, jika dilatih dengan metode compound set.

Program latihan beban metode circuit training akan lebih tepat jika diberikan pada atlet yang memiliki kekuatan otot rendah, dalam upaya menurunkan ketebalan lemak. Pelatih atau pembina olahraga disarankan merancang program latihan yang tepat dan terencana sesuai dengan cabang olahraga masing-masing. Hal ini disebabkan oleh kebutuhan hypertrophy otot dan ketebalan lemak setiap cabang olahraga berbeda-beda dan belum tentu suatu metode latihan sesuai atau cocok bagi semua kelompok.

\section{DAFTAR PUSTAKA}

Arikunto, S. (2006). Prosedur penelitian suatu pendekatan praktis. Edisi Revisi V. Jakarta: Bhineka Cipta.

Bompa. T. O., \& Haff, G.G. (2009). Periodization: Theory and metodology of training. Iowa: Kendall Hunt Publishing Company.

David, K. M. (2002). Measurement by the physical educator why and how. NewYork: Mcgraw-Hill Companies.

Dinata, Y., Sutardji, S., \& Waluyo, M. (2013). Perbedaan pengaruh latihan front cone hops dan latihan zig-zag drill terhadap peningkatan power otot tungkai.Journal Of Sport Sciences And Fitness, 2(1). Retrieved from http://journal.unnes.ac.id/sju/index. php/jssf/article/view/1945

Hasibuan, R. (2010). Perbedaan pengaruh latihan bicep curl tempo cepat dengan tempo lambat terhadap peningkatan kekuatan otot lengan pada members putra tiara hotel fitness center. Jurnal Ilmu Keolahragaan, Vol. 8, pp. 43-44.

Husein, et.al. (2007). Teori kepelatihan dasar. Jakarta: Kementerian Negara Pemuda.

Ilhamjaya, P. (2000). Fisiologi olahraga. Makasar: Fakultas Kedokteran Universitas Hasanudin. 


\section{Jurnal Keolahragaan 4 (1), April 2016 - 121}

Eko Sucipto, Widiyanto

Ilhamjaya, P. (2008). Pedoman kuliah pendidikan kesegaran jasmani. Yogyakarta: FIK UNY.

Irianto, D. P. (2000). Dasar-dasar latihan kebugaran. Yogyakarta: Lukman Offset.

Irianto, D. P. (2004). Pedoman praktis berolahraga untuk kebugaran dan kesehatan. Yogyakarta: Andi Offset.

Irianto, D. P. (2007). Panduan gizi lengkap utnuk keluarga dan olahragawan.Yogyakarta: Andi Offset.

Irianto, D. P., et al. (2009). Pelatihan kondisi fisik dasar. Asdep Pengembangan Tenaga dan Pembina Keolahragaan: Kementrian Pemuda dan Olahraga.

Power, S., \& Howlen, E. (2007). Exercise physiology. New York: McGraw-Hill Companies, Inc.

Rai, A., Hamid, L., \& Tsiang H. (2007). Gaya hidup sehat fitness dan binaraga. Jakarta: Tabloid BOLA.

Sharkey, J. B. (2011). Kebugaran \& kesehatan. (Eri Desmarini Nasution. Terjemahan).
New York: Human Kinetics Publishers, Inc. (Buku asli diterbitkan tahun 2003).

Sugiyono. (2007). Metode penelitian administrasi: Dilengkapi dengan Metode $R \& D$. Edisi 17. Bandung: Alfabeta.

Sudjana. (2002). Metode statistika. Bandung: Tarsito.

Suharjana. (2007). Latihan beban. Yogyakarta: FIK UNY.

Sukadiyanto. (2005). Pengantar teori dan metodologi melatih fisik. Yogyakarta: FIK UNY.

Sukadiyanto. (2010). Pengantar teori dan metodologi melatih fisik. Yogyakarta: FIK UNY.

Sukadiyanto. (2011). Pengantar teori dan metodologi melatih fisik. Bandung: Lubuk Agung.

Syah, M. (2003). Psikologi pendidikan dengan pendekatan baru. Bandung: Remaja Rosdakarya. 